\title{
Effect of Different Harvest Times on Some Quality Characteristics of Cultivated Sahlep orchid Serapias vomeracea (Burm.fill.) Brig.
}

\author{
Olcay ARABACI *1, Uğur TAN ${ }^{1}$, Özge YILDIZ², Mehmet TUTAR² \\ ${ }^{1}$ Adnan Menderes University, Faculty of Agriculture, Field Crops, 09100 Aydın, Turkey. \\ ${ }^{2}$ Aegean Agricultural Research Institute, Menemen-Izmir, Turkey
}

Received: 04 May 2017 - Revised: 18 June 2017 - Accepted: 03 August 2017

\begin{abstract}
Sahlep orchids are used as medicinal plants in Turkey to cure diarrheal, ulcers and respiratory ailments. Also, the main ingredient of traditional Turkish ice cream and sahlep drinks is obtained from the tubers of wild orchids. It is reported that sahlep is obtained from 38 different orchid plants belong to 10 different genera in Turkey. Sahlep is not have standard chemical composition due to obtaining from different species of Orchidaceae in different regions. Also, the sahlep chemical composition shows a fairly large change depending on the period that collected. In order to protect the Orchidaceae species in Turkey, "Sahlep" export has prohibited since 1974. Although there was a ban on exports, still millions of tubers are removed from nature every year and exported to many countries, especially European countries. Continuously collected tubers do not have any chance the produce new seeds and even if it produces seeds, these seeds have some difficulties to germinate. Due to there is intense collection of some species of sahlep orchids from nature, necessary measures must be taken to prevent it without delay. The aim of this study investigates the effect of different harvest times on some quality characteristics of Serapias vomerace (Burm. fill.) Brig. species which one of the most collected species in the Aegean region. In this study, starch ratio $(\%)$, mucilage ratio $(\%)$, protein ratio $(\%)$, moisture ratio $(\%)$, dry matter ratio $(\%)$ and ash ratio (\%) was investigated. According to the harvest time, mucilage ratio was found between 16-23\%.
\end{abstract}

Keywords: Cultivation, Harvest Time, Sahlep, Serapias vomerace (Burm.fill.). Brig., Quality.

\section{INTRODUCTION}

Turks are knew the sahlep since ancient times. Along with the acceptance of Islam religion in the 8th century, alcoholic beverages such as wine and kimiz were banned by the Islamic religion and such as boza, şıra and sahlep are started to take place. While şıra was preferred in the summer months, the sahlep which was served as a hot drink and boza are preferred to drink in the winter months. Sahlep also known as "çayırotu", "çemçiçeği" among the people to cure for colds, coughing and intestinal diseases. Sahlep is used to give rigidity, flexibility and a unique flavor in traditional Turkish ice cream [1].

Sahlep orchids are used as medicinal plants in Turkey to cure diarrheal, ulcers and respiratory ailments [2]. Also, the main ingredient of traditional Turkish ice cream and sahlep drinks is obtained from the tubers of wild orchids. It is reported that sahlep is obtained from 38 different orchid plants belong to 10 different genera in Turkey [3]. Sahlep is not had standard

\footnotetext{
*Corresponding Author E-mail: oarabaci@adu.edu.tr
} 
chemical composition due to obtaining from different species of Orchidaceae in different regions. Also, sahlep composition shows a fairly large change depending on the period that collected [4,5]. In order to protect the Orchidaceae species in Turkey, "Sahlep" export has prohibited since 1974 [6]. Although there was a ban on exports still millions of tubers are removed from nature every year and exported to many countries, especially European countries. According to the red book of Turkish plants, Ophrys isaura Renz et Taub., Ophrys lycia Renz\&Taub and Serapias parviflora Parl. from Orchidaceae families were at high risk for extinction (EN). Fourteen taxa are under threat (LR) and 10 taxa are in invulnerable (VU) species group [7]. On the other hand, it is known that the population of orchids in European countries has gradually decreased due to the disappearance of their habitats [8]. Continuously collected tubers do not have any chance the produce new seeds and even if it produces seeds, these seeds have some difficulties to germinate. Due to there is intense collection of some species of sahlep orchids from nature, the necessary measures must be taken to prevent it without delay [9]. The most effective measure for this issue is the cultivation of species that are threatened by intense collection.

The aim of this study investigates the effect of different harvest times on some quality characteristics of Serapias vomerace (Burm. fill.) Brig. species that one of the most collected species in the Aegean region.

\section{MATERIAL and METHODS}

The material was brought from another research that was conducted in Aegean Agricultural Research Institute. Serapias vomeracea (Burm.fill.) Brig. locally called "deaf ears" (Sağır kulăğ1) generally distribute in calcareous and clayey soils between 20-680 m altitude in dry or wet meadows, roadsides, and within olive groves [10,11]. Its distribution in Turkey is the outer parts of Anatolia (Canakkale, Balıkesir, Istanbul, Bolu, Samsun, Muğla, Aydın, Antalya, Adana and Hatay provinces) and Aegean Islands. Distribution of this species in the world is Greece, Aegean, and Cyprus [11].

This study was carried out during the period of 2012-2014 in Adnan Menderes University, Faculty of Agriculture Research, Application and Production field. The province of Aydin where the experiment was conducted, took place in the Mediterranean region and it was under the influence of temperate Mediterranean climate.

The soil that experiment was carried out has a straight structure. According to soil analysis results; loamy and limy soil (1.53\%), pH 7.89 and organic matter is very low $(0.57 \%)$, poor nitrogen nutrient $(0.05 \%)$, medium phosphorus $(11.91 \mathrm{~kg} / \mathrm{da})$, low potassium $(18.86 \mathrm{~kg} / \mathrm{da})$, medium calcium, iron, magnesium (respectively $2101 \mathrm{mg} / \mathrm{kg}, 84,06 \mathrm{mg} / \mathrm{kg}, 5.81 \mathrm{mg} / \mathrm{kg}$ ) zinc was sufficient $(0.71 \mathrm{mg} / \mathrm{kg})$.

The experiment was conducted according to the randomized block experimental design and 3 repetitions. The planting areas were $1 \mathrm{~m}$ wide and $25 \mathrm{~cm}$ high. The tubers were planted the first year in 15.10.2012 and second year in 11.10.2013. The prepared plots were planted at $20 \times 20 \mathrm{~cm}, 36$ tubers were used for each parcel and total 432 tubers were used in the experiment. The removal of weeds was made with the hoe when necessary during the growth of the plants. Plants have benefited from rainfall due to good rainfall during the vegetation process so there was no needed for irrigation.

The harvest has begun with blooming of plants. The tubers were harvested in four periods (beginning of blooming, full blooming, blooming end and seed maturity). Harvest was made in the first year between 17/04/2013-17/05/2013 and in the second year between 14/04/201414/06/2014. Quality analyzes were carried out at Aegean Agricultural Research Institute Technology Laboratory. Preliminary preparations before the analysis were carried out at the Medical Plants Laboratory of the Field Crops Department of ADU Agriculture Faculty. 
Due to a high number of quality analyses, trial replications were combined and analyses were carried out in parallel. For this reason, the data have not subjected to statistical analysis and were interpreted in a table form for information purposes.

\section{RESULTS and DISCUSSIONS}

According to harvesting periods (beginning of blooming, full blooming, blooming end and seed maturity), determined some quality characteristics of Serapias vomeracea (Burm.fill.) Brig. were given in Tables 1-2 and Figure 1-2. The starch ratio was varied between 4.802$17.339 \%$ in the first year, $12.028-25.487 \%$ in the second year and $8.415-21.413 \%$ for a mean of both years. When determined values was taken into consideration, the highest starch ratio was obtained at blooming end and the lowest starch ratio was obtained at beginning of blooming (Table 1 and Figure 1).

While a two-year average of mucilage ratio was calculated as $20.2 \%$, the value of the first year was determined as $18.8 \%$ and second year as $21.6 \%$. According to the years of experiment (first and second year) and the average, the highest mucilage ratio was obtained at full blooming period $(20 \%, 23 \%$ and $21.5 \%$, respectively). It was observed that the ratio of mucilage decreased during the seed stage of the plant (Table 1 and Figure 1).

Protein ratio was reached the highest value with the seed stage $(14.968 \%, 15.9 \%$ and $15.448 \%$ respectively). The lowest value of protein ratio was obtained at the beginning of flowering (11.692\%, $10.735 \%$ and $11.214 \%$, respectively). It was determined that late harvest was more suitable for high protein ratio (Table 1 and Figure 1).

Table 1. Effects of harvest times on starch, mucilage and protein ratios (\%) on Serapias vomeracea (Burm.fill.) Brig.

\begin{tabular}{lccccccccc}
\hline \multirow{2}{*}{ Harvest Time } & \multicolumn{3}{c}{ Starch Ratio $(\%)$} & \multicolumn{3}{c}{ Mucilage Ratio $(\%)$} & \multicolumn{3}{c}{ Protein Ratio (\%) } \\
& 1. Year & 2. Year & Avg. & 1. Year & 2. Year & Avg. & 1. Year & 2. Year & Avg. \\
\hline Begin. Blooming & 4.802 & 12.028 & 8.415 & 20 & 21.2 & 20.6 & 11.692 & 10.735 & 11.214 \\
Full Blooming & 12.188 & 15.845 & 14.016 & 20 & 23 & 21.5 & 13.496 & 10.996 & 12.246 \\
Blooming End & 17.339 & 25.487 & 21.413 & 19 & 21 & 20 & 13.740 & 11.643 & 12.692 \\
Seed Stage & 14.347 & 20.487 & 17.417 & 16 & 21 & 18.5 & 14.968 & 15.927 & 15.448 \\
Avg. & 12.169 & 18.462 & 15.315 & 18.8 & 21.6 & 20.2 & 13.474 & 12.325 & 12.900 \\
\hline
\end{tabular}



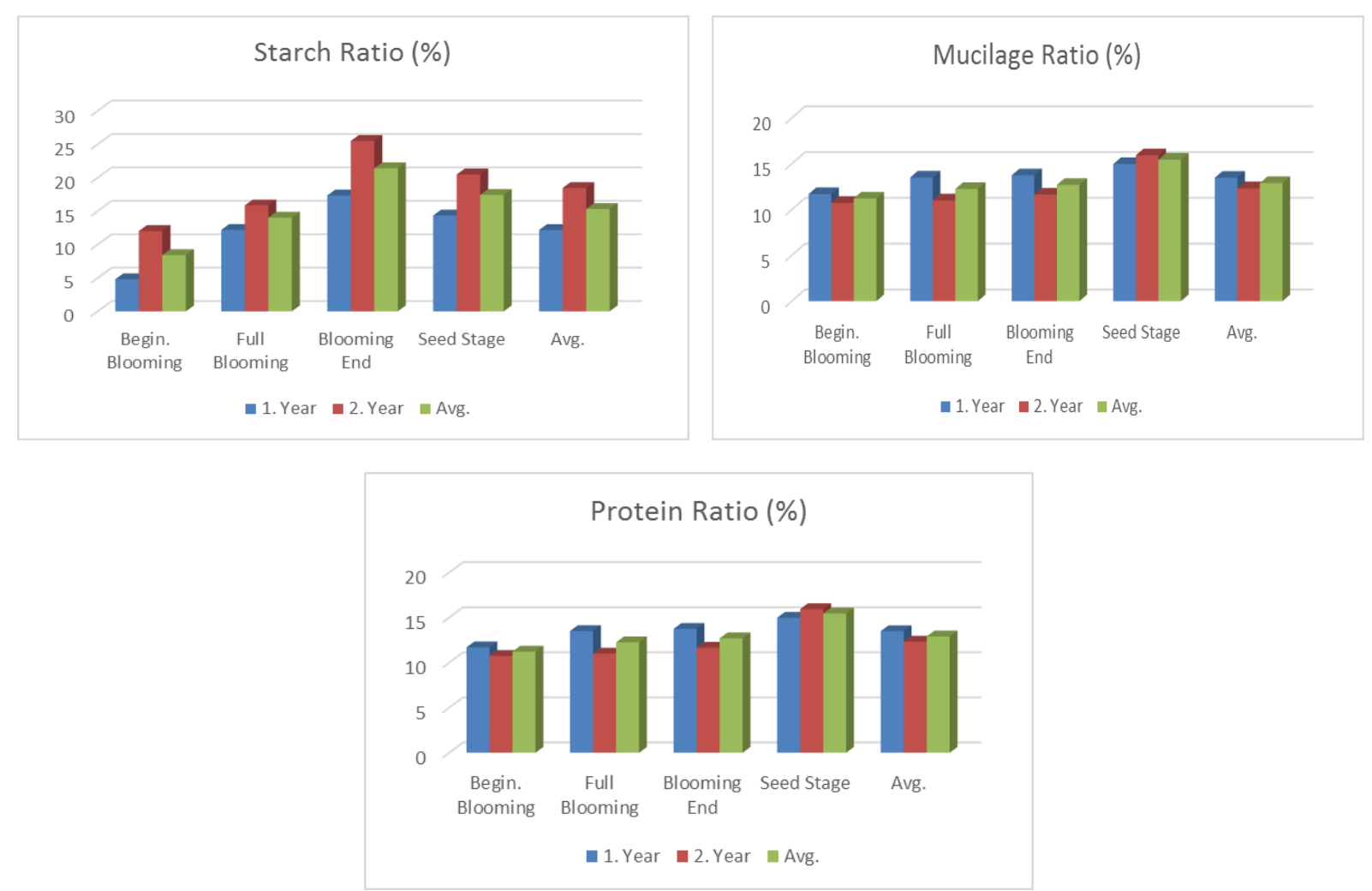

Figure 1. Starch, mucilage and protein ratios (\%) of Serapias vomeracea (Burm.fill.) Brig.

The highest values of moisture ratio, dry matter and ash ratio were obtained from full flowering (9.57\%), seed stage $(91.53 \%)$ and beginning of blooming $(5.27 \%)$ respectively. The ash ratio of early harvests and dry matter ratio of late harvests were found higher than other harvest times (Table 2 and Figure 2).

Table 2. Effects of harvest time on moisture, dry matter and ash ratios (\%) on Serapias vomeracea (Burm.fill.) Brig.

\begin{tabular}{lccccccccc}
\hline \multirow{2}{*}{ Harvest Time } & \multicolumn{3}{c}{ Moisture Ratio (\%) } & \multicolumn{3}{c}{ Dry Matter Ratio $(\%)$} & \multicolumn{3}{c}{ Ash Ratio (\%) } \\
& 1. Year & 2. Year & Avg. & 1. Year & 2. Year & Avg. & 1. Year & 2. Year & Avg. \\
\hline Begin. Blooming & 8.89 & 9.70 & 9.29 & 91.11 & 90.3 & 90.71 & 4.62 & 5.92 & 5.27 \\
Full Blooming & 9.03 & 10.11 & 9.57 & 90.97 & 89.89 & 90.43 & 5.17 & 4.91 & 5.04 \\
Blooming End & 8.97 & 9.89 & 9.43 & 91.03 & 90.11 & 90.57 & 4.05 & 3.58 & 3.82 \\
Seed Stage & 8.95 & 7.99 & 8.47 & 91.05 & 92.01 & 91.53 & 5.13 & 3.92 & 4.53 \\
Avg. & 8.96 & 9.42 & 9.19 & 91.04 & 90.58 & 90.81 & 4.74 & 4.58 & 4.66 \\
\hline
\end{tabular}



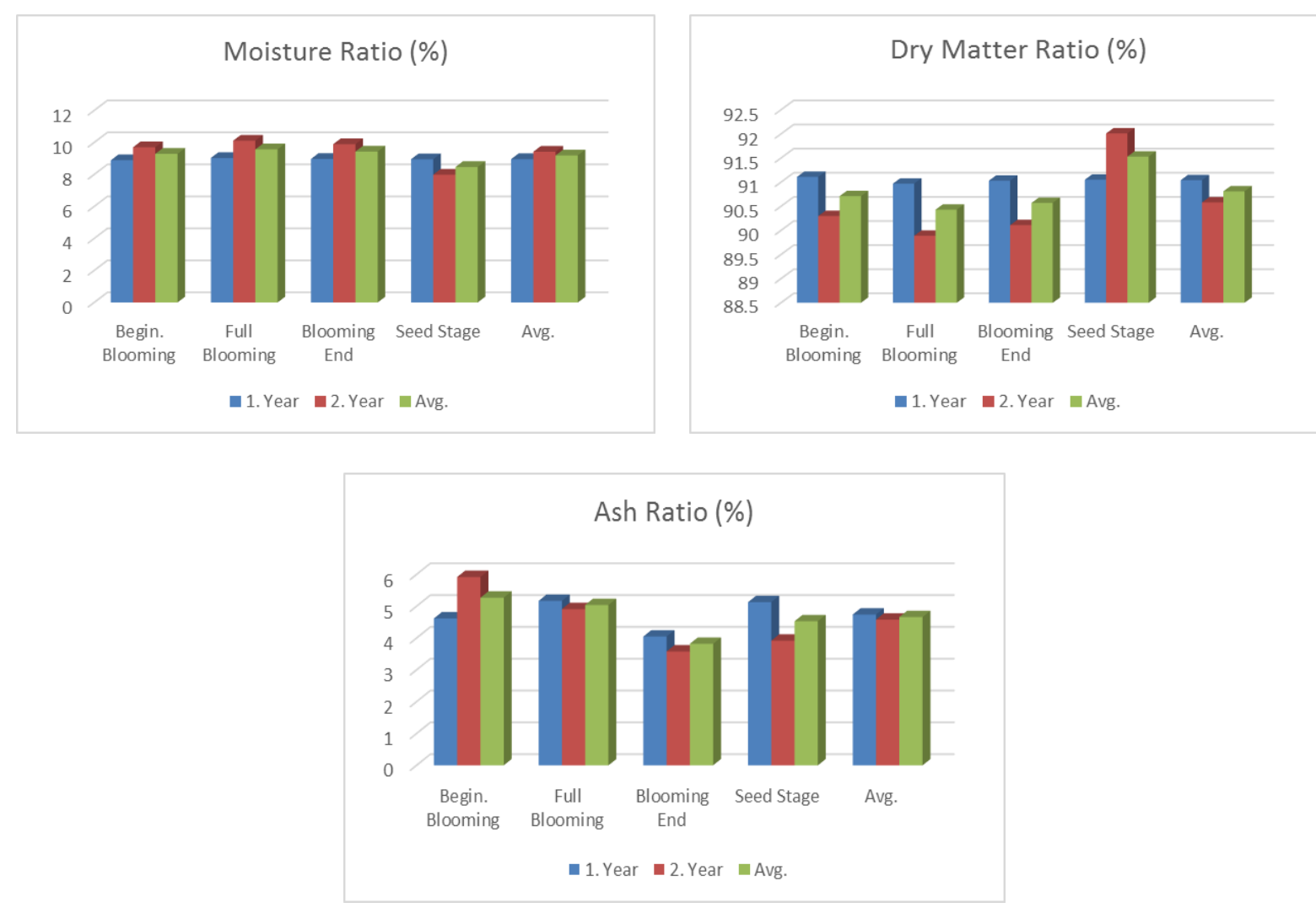

Figure 2. Effects of harvest time on moisture, dry matter and ash ratios (\%) on Serapias vomeracea (Burm.fill.) Brig.

\section{DISCUSSION}

The most important ingredient in the sahlep is mucilage that contain glucomannan structure [12]. It has been reported that commercial sahlep in Turkey contains, 11.62-44.04\% mucilage, $8.40-19.13 \%$ starch, $0.58-1.24 \%$ total N, 8.62-12.38\% moisture and $2.45-9.64 \%$ ash [13]. On the other hand, the researcher determined that mucilage ratio, starch ratio, moisture ratio and ash ratio of Serapias vomeracea L. was $40.56 \%, 1.35 \%, 8.70 \%$ and $1.43 \%$ respectively. He also noted that except glucomannan, quality also affected by starch, ash and moisture [13]. It was reported that there were differences in sahlep chemical content depending on species of wild orchids [4]. It was found that according to chemical analysis results, the commercial sahleps of Kastamonu have average of 31.08-46.70\% glucomannan, 7.31-15.17\% starch, 1.39-2.29\% ash and 7.77-13.09\% moisture values [12].

It was reported that the active sahlep substances were changed by the collection period and the composition of sahlep generally has mucilage (6-61\%), starch (0.6-36\%), reducing sugar (0.4-4.5\%), Non-reducing sugar (0,1-2,3\%), total nitrogen $(0.4-1.2 \%)$, water $(6-12 \%)$ and ash (0.2-9\%) [5]. According to the findings of Tekinşen and Güner (2009), values (moisture, glucomannan, starch, protein and ash content) of different collected sahlep species those growing in Kahramanmaraş region was determined as between 9.35-12.40\%, 17.65-54.62\%, $5.44-54.79 \%, 3.11-4.95 \%$ and $0.95-2.83 \%$ respectively [14].

Researchers have determined the quality of sahlep in the previous studies, which they had collected from their study area. However, our study aim was a determination of the quality of Serapias vomeracea grown in field conditions. When we compare our findings with the values that reported by Sezik (1967), it was determined that the mucilage ratio, starch ratio, Moisture ratio, and ash ratio were higher than the findings of the researcher [13]. 
Many factors such as species, climate, altitude, soil characteristics and harvesting time can affect the quality of sahlep orchids. On the other hand, data of material of present studies, collected from the flora and in our study material was obtained from the plants grown in the field conditions were close or similar to the natural plants.

\section{CONCLUSION}

Effect of different harvest times on some quality characteristics of cultivated sahlep orchid Serapias vomerace (Burm.fill.) Brig. was investigated. The highest values of starch ratio $(8.415-21.413 \%)$ and the lowest values of ash content (3.82-5.27\%) were obtained from end of blooming. Mucilage ratio ranged from 18.5 to $21.5 \%$ and the highest value was obtained from the full blooming stage. The highest values for protein ratio (11.214-15.448\%), dry matter ratio (90.43-91.53\%) and lowest values for moisture (8.47-9.57\%) were recorded from the seed stage. Some quality results of Serapias vomeracea (Burm.fill.) species that grown in field conditions were similar to the qualities of plants grown in natural conditions. These results indicate that quality parameters will be better in near future.

\section{Acknowledgement}

This study was part of ADU BAP project (ZRF-13003).

\section{Conflict of Interests}

Authors declare that there is no conflict of interests.

\section{REFERENCES}

[1]Anonim, (2011). Retrieved from: http:// www.lokmanhekimimiz.com/1149/ Urunlerimiz/Sifali-Bitkiler/ Salep-Hakiki-Saf-Salep- SAHLEP-50-GR.aspx.

[2] Oğuz, B., Sarı, A.O., \& Bilgiç, A., (2005). Ege Bölgesinde Yayılış Gösteren Bazı Salep Orkidelerinin Üretim Olanaklarının Araştırılması, Tagem Proje Sonuç Raporu, Proje No: Tagem/Ta/02/02/03/010.

[3] Sezik, E., (1984). Orkidelerimiz (Türkiye'nin Orkideleri), Sandoz Kültür Yayınları No.6, pp.166.

[4] Baytop, T., \& Sezik, E., (1968). Türk Salep Çeşitleri Üzerinde Araştırmalar, Journal of the Faculty of Pharmacology 4: pp.61-68.

[5] Akgül, A., (1993). Baharat Bilimi ve Teknolojisi, Gıda Teknolojisi Derneği Yayınları, Ankara pp.142-143.

[6] Baytop, T., (1999). Türkiye'de Bitkiler ile Tedavi, İ.̈̈. Ecz. Fak. Yayın No: 325540/40 İstanbul pp.326-327.

[7] Ekim, T., Koyuncu, M., Vural, M., Duman, H., Aytaç, Z., \& Adıgüzel, N., (2000). Türkiye Bitkileri Kırmızı Kitabı (Eğrelti ve Tohumlu Bitkiler), Türkiye Tabiatını Koruma Derneğ $i$ Yayınlarl, Yayın No: 18, Ankara, s.24, 123-124,180.

[8] Tamer, C.E., Karaman, B., Aydoğan, N., \& Çopur, Ö.U., (2004). Geleneksel Bir İçeceğimiz; Salep. Geleneksel Gidalar Sempozyumu. 23-24 Eylül. Van. 100-103.

[9] Arabacı, O., Tutar, M., Özcan, İ.İ., Öğretmen, N.G., \& Yıldız, Ö., (2016). Aydın Ekolojik Koşullarında Salep Orkidelerinin Agronomik ve Teknolojik Özelliklerinin Belirlenmesi, ADÜ BAP ZRF-13003 nolu Projenin Sonuç Raporu S.104.

[10] Sezik, E., (1990). Türkiye'nin Orkideleri, Bilim Teknik, s5-9. 
[11] Güler, N., Gönüz, A., Hürkan, K., \& Döver, E., (2008). Çan (Çanakkale-Türkiye) İlçesi Doğal Yayılışlı Bazı Orchidaceae Taksonları Üzerine Gözlemler, Çan Değerleri Sетроzуити 28-29 Ağustos, pp.143-168.

[12] Sezik, E., \& Özer, B., (1983). Kastamonu Salebinin Menşei ve Kastamonu Civarının Orkideleri. TÜBİTAK Proje No: TBAG -424, Ankara.

[13] Sezik, E., (1967). Türkiye'nin Salepgilleri Ticari Salep Çeşitleri ve Özellikle Muğla Salebi Üzerinde Araştırmalar. Doktora Tezi, Ístanbul Üniversitesi, Eczacılık Fakültesi Farmakognozi Kürsüsü, İstanbul.

[14] Tekinşen, K.K., \& Güner, A., (2009). Kahramanmaraş Yöresinde Yetişen Saleplerin Kimyasal Bileşiminin ve Bazı Fizikokimyasal Niteliklerinin Araştırılması, S. U. BAP Proje No: 06401061, Konya. 